\title{
暴浪波と静穏波の繰り返し作用に伴うへッドランド間の 海浜変形過程に関する実験的研究
}

\author{
山本幸 次*・鳥居 謙 一**
}

\begin{abstract}
波が斜めから入射し沿岸漂砂が生じる条件下で，暴浪波と静穏波の繰り返し作用によるへッドランド間の海浜変形過程に 関する移動床平面実験を行った。 その結果, 沿岸漂砂の上手側では暴浪波と静穏波の作用で汀線が後退するとともにバーが 徐々に消滅する変形過程を, 沿岸漂砂下手側では暴浪波の作用で前浜部分が侵食されるものの沖浜が形成され, 静穏波の作 用で前浜が復元する変形過程を明らかにした。 また，ヘッドランド間の土砂収支は暴浪波作用後には増加し，静穏波作用後 には減少するが，暴浪波と静穏波の作用後の 1-cycle 後にはほぼ均衡することが新たな知見として得られた。
\end{abstract}

\section{1. はじめに}

1999 年 5 月 28 日に公布された改正「海岸法」のもとで は，海岸管理者が消波等の海岸を防護する機能を維持す るために設けたもので，指定したものに限り，砂浜も海 岸保全施設として認められるようになった。特に，大規 模な突堤（ヘッドランド）で囲まれた土砂収支の閉じた 区間に養浜により創出した砂浜は，海岸保全施設として 指定・管理されることになる。この場合，現地海岸では 気争擾乱時の暴浪波や常時の静穏波が繰り返し来襲する ことから，指定する範囲での岸沖方向と沿岸方向におけ る土砂動態を把握し, 砂浜の侵食限界や安定性を評価し ておく必要がある。

ところで，気象擾乱時のように，時間的に変動する波 浪の作用に伴う岸沖方向の海浜縦断面の時間的変化につ いては, 砂村・倉田 (1981)や福島ら (1999), 岡田ら (2000) による実験や，栗山（1996）や山本ら（1999）による現 地データの解析などでかなりの知見が得られている。し かし, 沿岸漂砂が卓越する条件下での, 時間的に変動す る波浪の作用による海浜縦断面の変化過程に関する研究 はほとんど行われていない，そこで，本研究では沿岸漂 砂が生じる海岸における, 暴浪波と静穏波の繰り返し作 用に伴う，土砂収支の系が閉じたへッドランド間の海浜 変形過程を移動床平面実験により検討した。

\section{2. 実験方法}

実験で使用した平面水槽は，図一1に示すように幅 30 $\mathrm{m}$, 長さ $30 \mathrm{~m}$, 深さ $1 \mathrm{~m}$ の諸元を有し, その中には造波 板幅 $8 \mathrm{~m}$ のピストン式造波機が 3 台設置してある. 実験 では平面水槽内を導波板で区切り, その左側の導波板に 原点 $\mathrm{O}$ を設け，沿岸方向に $X$ 軸を，岸沖方向に $Y$ 軸を とった．この場合，導波板に対し $Y$ 軸を時計回りを正と して 15 傾け, 波浪が左斜めから入射し沿岸漂砂が卓越す る条件にした. そして, $X=0 \sim 22.1 \mathrm{~m}, Y=0 \sim 8 \mathrm{~m}$ に中

$*$ 正会員 博 (工) 国土交通省国土技術政策総合研究所 河川研究部海 岸研究室主任研究官

** 正会員 工 修 国土交通省四国地方整備局 大洲河川国道事務所長 (元国総研海岸研究室長)

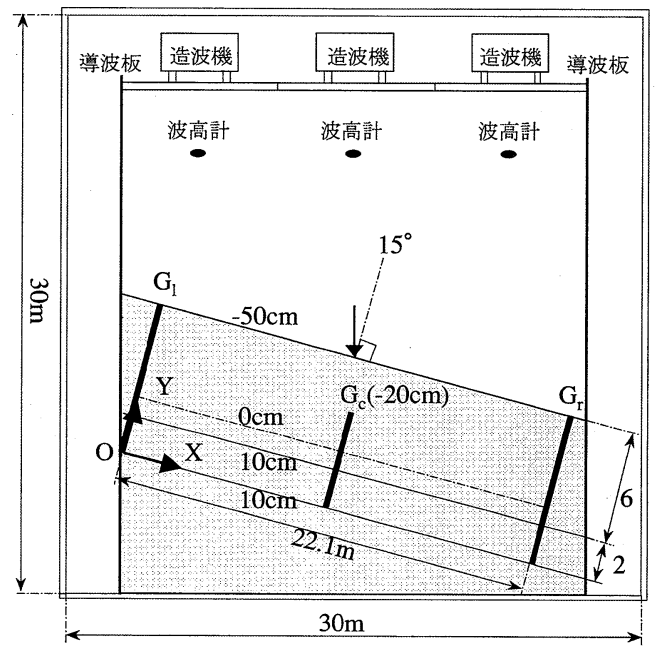

図-1 平面水槽と模型海浜の諸元

央粒径 $d_{50}=0.3 \mathrm{~mm}$ の実験砂を用いて模型海浜を製作 した. また， $Z$ 軸の基準は平面水槽底面から $50 \mathrm{~cm}$ の静 水面とし, $Y=0 \sim 2 \mathrm{~m}$ は天端高が $Z=10 \mathrm{~cm}$ の平坦面 で, $Y=2 \sim 8 \mathrm{~m}(Z=10 \sim-50 \mathrm{~cm})$ までが $i=1 / 10$ の一 様勾配斜面からなる海浜縦断面とした。 したがって, 初 期汀線は $Y=3 \mathrm{~m}$ の位置になる.

また, 左右端の $X=0 \mathrm{~m}$ と $X=22.1 \mathrm{~m}$ には初期汀線 からの堤長 $5 \mathrm{~m}$ （初期先端水深 $Z=-50 \mathrm{~cm}$ ）の突堤 $G$, 突堤 $G_{r}$ を, 中間地点の $X=11.0 \mathrm{~m}$ には初期汀線からの 堤長 $2 \mathrm{~m}$ （初期先端水深 $Z=-20 \mathrm{~cm}$ ）の突堤 $G_{c}$ を設置 した.これらの突堤は合板で製作し, 沿岸漂砂を阻止す る不透過構造とした。なお, 以下では突堤 $G$ と突堤 $G_{c}$ の間を区間 I, 突堤 $G_{c}$ と突堤 $G_{r}$ の間を区間 II とする.

以上の模型海浜に左斜めから入射する静穏波 $(H=4.0$ $\mathrm{cm}, T=1.6 \mathrm{~s})$ を 190 分作用させ, 形成された地形を初 期地形 $(t=190 \mathrm{~min})$ とした. その後, 暴浪波 $(H=10.0$ $\mathrm{cm}, T=1.6 \mathrm{~s})$ を 30 分, 静穏波 $(H=4.0 \mathrm{~cm}, T=1.6$ s）を 190 分作用させる cycleを 3 回繰り返して海浜変形 過程を調べた。なお,初期条件から完全移動限界水深 $\left(h_{c}\right)$ と, 海浜縦断面の変化を分類する指標 $\left(C_{s}\right)$ を求めると, 
静穏波で $h_{c}=5.5 \mathrm{~cm}, C_{s}=3.4$ (バーム形成・汀線前進 型), 暴浪波で $h_{c}=18.0 \mathrm{~cm}, C_{s}=8.5$ (バー形成・汀線後 退型）となる.ここで, 突堤 $G_{1}$ と突堤 $G_{r}$ の先端水深は $h=-50 \mathrm{~cm}$ で沿岸漂砂を完全に遮断するので, これらは 大規模なへッドランドと考え, 中央突堤 $G_{c}$ の先端水深 は $h=-20 \mathrm{~cm}$ で暴浪波作用時には沿岸漂砂が通過する 可能性があるので，これはやや規模の小さなヘッドラン ドと仮定した。

\section{3. 実 験 結 果}

\section{（1）入射波の測定結果}

模型海浜の沖側の 3 地点 (図一 1 参照) に設置した波高 計で得られた入射波高を平均して，その経時変化を示し たのが図一2である. 初期地形を形成させた $t=0 \sim 190$ $\min$ の静榣波は波高が約 $4 \mathrm{~cm}$, その後の cycle -1〜 cycle- 3 では暴浪波は波高が約 $10 \mathrm{~cm}$ ，静穏波は波 高が約 $4 \mathrm{~cm}$ であった。したがって, 実験で設定した暴浪 波と静穏波の繰り返し作用条件をほほ満足していると言 える.

\section{（2）汀線形状の経時変化}

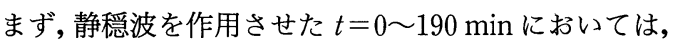
静穏波の作用により区間 I では突堤 $G_{1}$ の下手側の $X=$ 0 5 $\mathrm{m}$ で汀線が後退し, 突堤 $G_{c}$ の上手側の $X=5 \sim 11$ $\mathrm{m}$ で汀線が前進した（図一3)。同様に，区間IIでも突堤 $G_{c}$ の下手側の $X=11 \sim 17 \mathrm{~m}$ で汀線が後退し, 突堤 $G_{r}$ の 上手側の $X=17 \sim 22 \mathrm{~m}$ で汀線が前進した. 以上のこと から，区間 I と区間II ともに，左側から右側への沿岸漂 砂に伴う汀線形状の変化が生じたことが分かる.

$t=190 \mathrm{~min}$ の海浜地形を初期地形とした cycle- 1 の汀 線形状の経時変化を図一 4 に示す. 暴浪波作用後の $t=$ $220 \mathrm{~min}$ では区間 I の $X=0 \sim 8 \mathrm{~m}$ と区間 II の $X=$ 11〜20 m で汀線が後退した.これに比較して汀線が前進 したのは，区間 I では $X=8 \sim 11 \mathrm{~m}$ ，区間 II では $X=$ 20〜21 m であり, 汀線後退範囲より汀線前進範囲がかな り小さい.したがって，暴浪波の作用により沿岸漂砂に 比較して岸沖漂砂に伴う海浜変形が卓越したと言える.

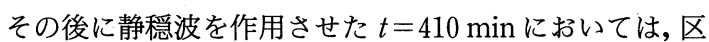
間 I と区間 II ともに中間地点では汀線が $t=190 \mathrm{~min}$ の 位置までほぼ復元した。また，突堤 $G_{1}$ と突堤 $G_{c}$ の下手 側で汀線の後退が, 突堤 $G_{c}$ と突堤 $G_{r}$ の上手側で汀線の 前進が進んだ. 以上のことから, $t=220 \sim 410 \mathrm{~min}$ では岸 沖漂砂による汀線の復元と, 沿岸漂砂に伴う突堤近傍で の汀線の後退と前進が進んだことが確認できる.

同様に，図一5に示した cycle-2 でも暴浪波の作用に よる汀線の後退が, 静榣波の作用に伴う汀線の回復と突 堤近傍での汀線の後退と前進が見られる。ただし，静穏 波作用時における沿岸漂砂に伴う汀線変化は, cycle-1

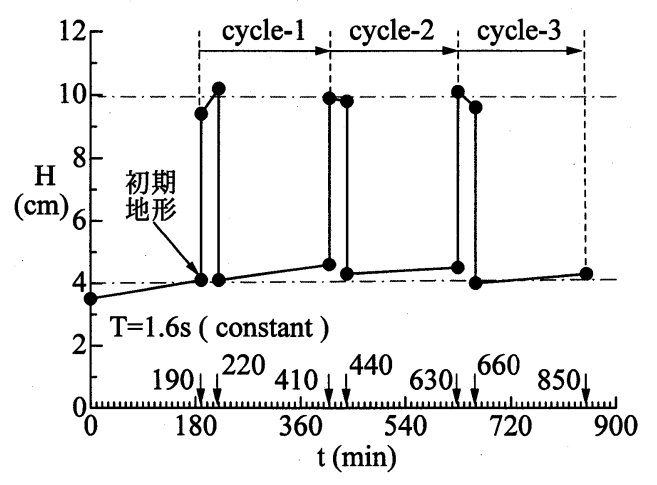

図-2 計測された入射波の波高

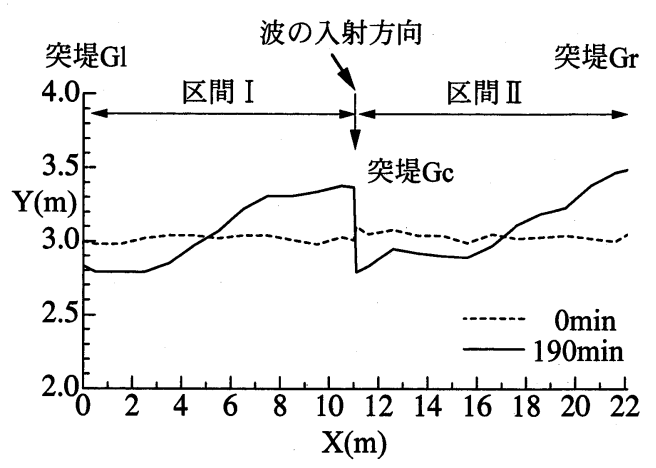

図一3 静榣波の作用による整形後の汀線形状の変化

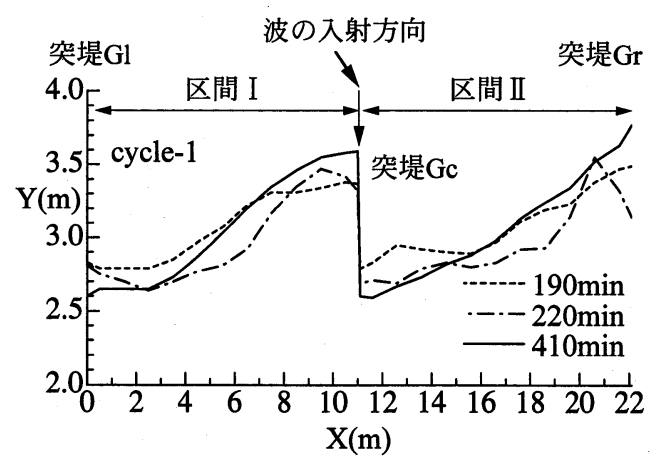

图一-4 cycle-1における汀線形状の経時変化

に比較して小さくなった。さらに, cycle-3では図一6に 示すように，暴浪波の作用による汀線の後退と静穏波の 作用による汀線の復元が, cycle- 1 および cyce- 2 とほほ 同じように生じた。しかし，静榣波作用の沿岸漂砂に伴 う突堤近傍の汀線の前進と後退はほとんどなくなった。 つまり， cycle-3では波の入射方向に対してほほ安定な 汀線形状になっており，静穏波の作用では沿岸漂砂がほ とんど生じない海浜地形が形成されていると推定でき る.また，区間 I の $X=7 \sim 11 \mathrm{~m}$ と区間 II $X=17 \sim 22$ $\mathrm{m}$ では cycle-3においては汀線の変化はほとんど見られ 


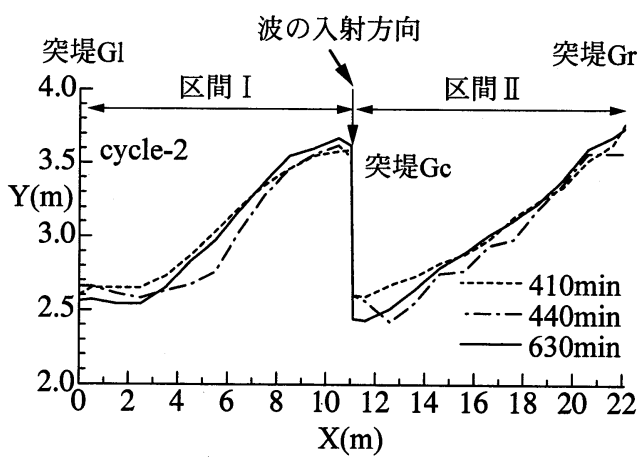

図一5 cycle-2 に扔ける汀線形状の経時変化

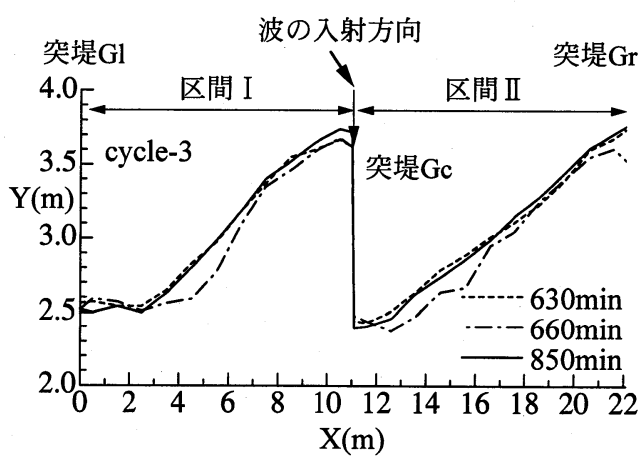

图一6 cycle-3 における汀線形状の経時変化

ず，沿岸漂砂の堆積域では暴浪波の作用に対しても安定 な海浜地形になったと言える。

\section{（3）代表測線における海浜縦断面の経時変化}

区間 I の代表測線における cycle-1 での海浜縦断面の 経時変化を図一 7 に示す. 突堤 $G$ の下手側に抢ける侵食 域の $X=0.0 \mathrm{~m}$ では, 暴浪波作用後の $t=220 \mathrm{~min}$ には前 浜部分はほとんど変化しなかったが，沖側にバーが形成 された。しかし, 静穏波の作用により $t=410 \mathrm{~min} に は$ バーが消滅して, 前浜部分が後退した。 中間地点の $X=$ $5.5 \mathrm{~m}$ では暴浪波作用後に前浜部分が侵食され，その沖 にバー状の地形が形成された。 その後の静穏波の作用で 前浜部分は復元されたが，沖側のバー状の地形は消滅し た. 突堤 $G_{c}$ の上手側における堆積域の $X=11.0 \mathrm{~m}$ で は, 暴浪波の作用で水面より陸側が侵食されたが，水面 下には砂が堆積しバーの形成も見られる。そして，その 後の静穏波の作用で前浜部分が復元した。

区間 I では各測線における cycle-1 での海浜縦断面の 変化過程は cycle-2 および cycle-3(図一8)でも繰り返さ れたが，変化量は徐々に小さくなった。特に，侵食域の $X=0.0 \mathrm{~m}$ では cycle- 3 では海浜縦断面はほとんど変化 しておらず, 堆積域の $X=11.0 \mathrm{~m}$ では最終的には移動 限界水深付近にバー状の地形が形成された。このため,

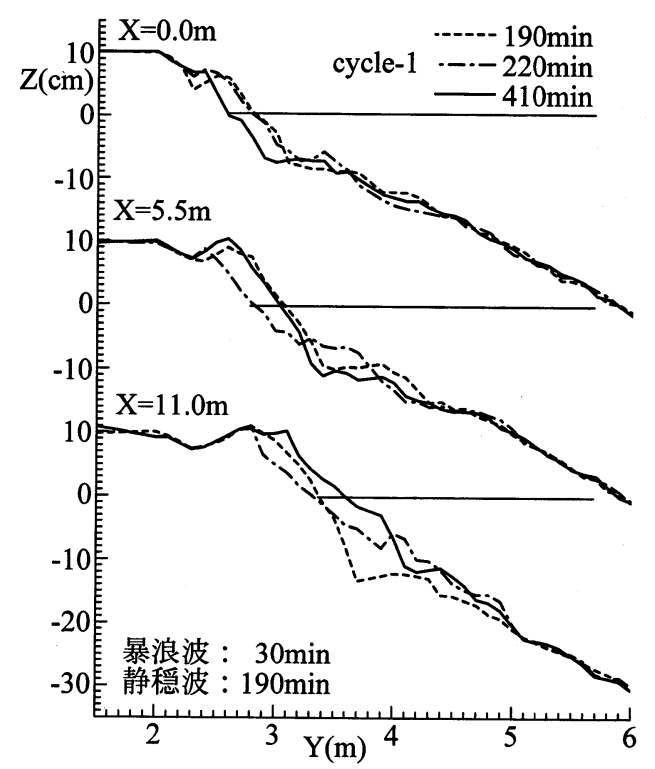

图一7 区間 I の cycle-1 における海浜縦断面の経時変化

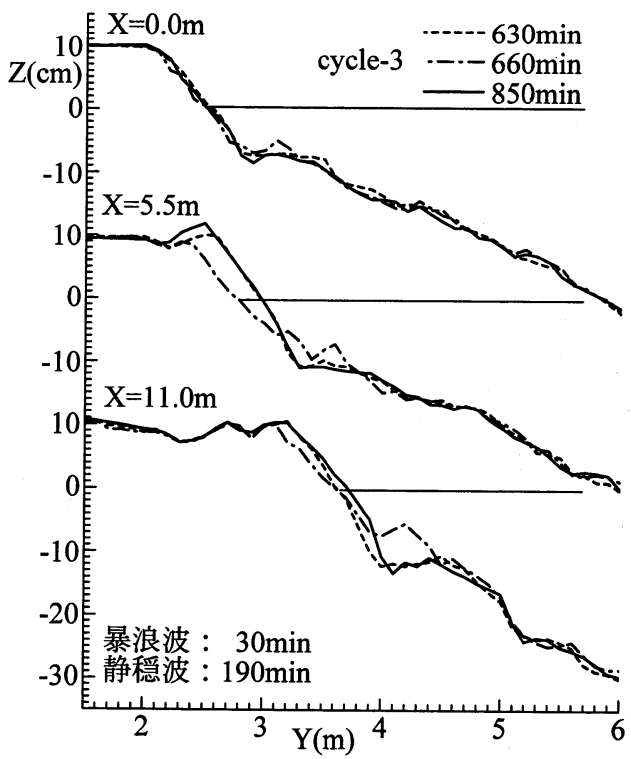

図一8 区間 I の cycle-3 における海浜縦断面の経時変化

侵食域と中間地点では鉛直上方に凹状の海浜縦断面に なったのに対し，堆積域では鉛直上方に凸状の形状の沖 側にバー状の地形が付随したような海浜綐断面となっ た.

区間IIの代表測線における cycle-1 での海浜縦断面の 経時变化を図一9 に示す. 突堤 $G_{c}$ の下手側における侵食 域の $X=11.1 \mathrm{~m}$ では，暴浪波作用後の $t=220 \mathrm{~min} に は$ 前浜部分はやや侵食され，沖側にバーが形成された。し

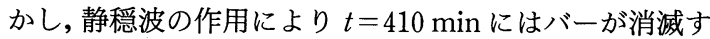




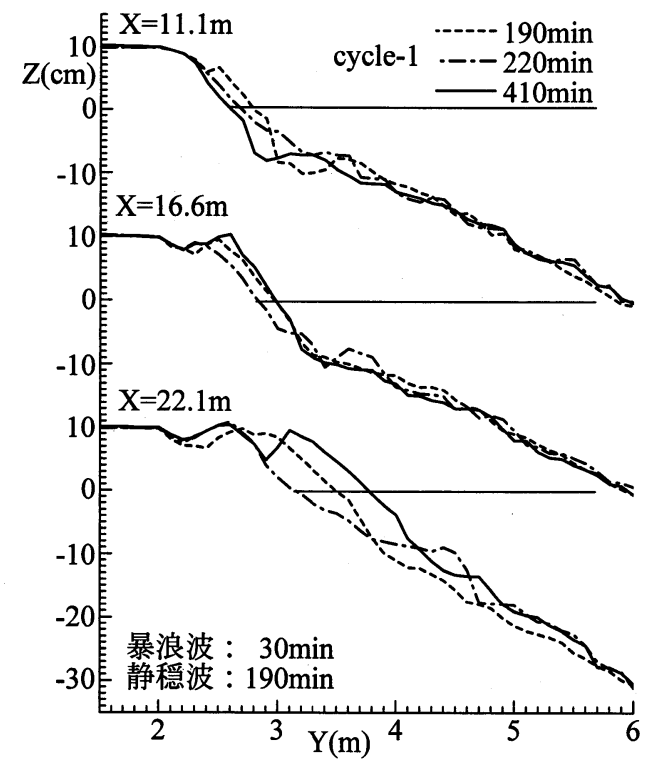

图一9 区間II

るとともに，前浜部分が後退した。中間地点の $X=16.6$ $\mathrm{m}$ では暴浪波作用後に前浜部分が侵食され，その沖に砂 が堆積してバーが形成された。 その後の静穏波の作用で 前浜部分は復元されたが，沖側のバーは消滅した。突堤 $G_{r}$ の上手側における堆積域の $X=21.1 \mathrm{~m}$ では, 暴浪波 の作用で $Y=2.7 \sim 3.8 \mathrm{~m}$ の範囲が侵食されたが, 水面 下には砂が堆積しバー状の地形の形成も見られる。静穏 波の作用後の $t=410 \mathrm{~min}$ には前浜部分にも砂が堆積し, ほほ一様な勾配の海浜縦断面となるとともに, 陸上部に は 2 列のバーム（浜堤列）が形成された。

cycle-2 になると侵食域の $X=11.1 \mathrm{~m}$ における海浜 縦断面の変化過程は cycle-1 とほほ同じであったが, 中 間地点の $X=16.6 \mathrm{~m}$ では前浜の変化はほとんどなく, 暴浪波作用後におけるバーの形成と静穏波作用後のバー の消滅が見られるのみとなった。 また, 堆積域の $X=$ $22.1 \mathrm{~m}$ では暴浪波の作用による前浜部分の後退とバー の形成, 静穏波の作用でのバーの消滅と前浜の復元が見 られたが, $t=410 \mathrm{~min}$ と $t=630 \mathrm{~min}$ の海浜縦断面はほ とんど変化していなかった.さらに, 図一10に示した cycle-3になると, 侵食域と中間地点では暴浪波作用後 におけるバーの形成と静穏波作用後のバーの消滅が見ら れるのみになった.また, 堆積域では cycle-2 とほほ同じ 海浜縦断面の変形過程を示した。 そして, 侵食域と中間 地点では鉛直上方に凹状の海浜綐断面に，堆積域では鉛 直上方に凸状の海浜縦断面となった。

\section{（4）土砂収支の経時変化}

最後に, 突哫 $G$ と突堤 $G r$ ひ間ひ侵食土砂量 $(V e)$ と 堆積土砂量 $(V a)$ を算出し, それらを加算して土砂収支

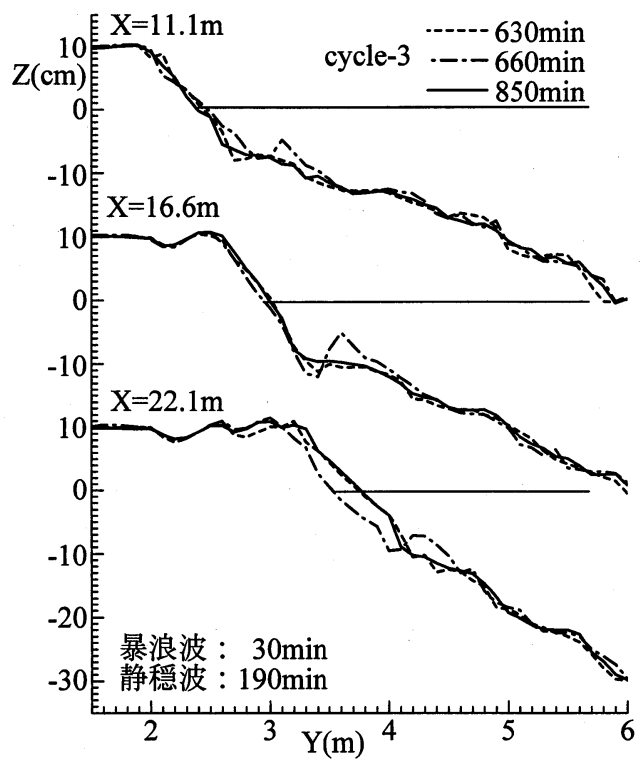

図一10 区間II の cycle-3における海浜縦断面の経時変化

$(V t)$ を求めた。まず，海浜縦断面の測定時間毎の土砂収 支を図一11 に示すが, $t=0 \sim 190 \mathrm{~min}$ では侵食土砂量が かなり大きく, 堆積土砂量が小さいため, 土砂収支が $V t=-800.3 \times 10^{-3} \mathrm{~m}^{3}$ (黒棒) と大きい負の值となった. その後は暴浪波作用後には土砂収支が正の值 $\left(94.6 \sim 182.9 \times 10^{-3} \mathrm{~m}^{3}\right)$ となり，静穏波作用後は土砂収 支が負の值 $\left(-207.0 \sim-198.8 \times 10^{-3} \mathrm{~m}^{3}\right)$ となった。

つまり, $t=190 \mathrm{~min}$ 以降は暴浪波作用後に正の土砂収 支, 静穏波作用後に負の土砂収支となるパターンの繰り 返しとなっていることが分かる，そこで，暴浪波と静穏 波を継続して作用させたと考えることのできる cycle1 cycle-3 の土砂収支を検討した. その結果を示した図 -12 によれば, cycle-1では土砂収支が $V t=-112.4 \times$ $10^{-3} \mathrm{~m}^{3}$ (黒棒) となったが, cycle- 2 では $V t=-19.0 \times$ $10^{-3} \mathrm{~m}^{3}$, cycle-3では $V t=-16.3 \times 10^{-3} \mathrm{~m}^{3}$ と土砂収支が ほほ均衡するようになった。

\section{4. 考察}

まず，ヘッドランド間の区間 I と区間 II で海浜綐断面 の変形過程がやや異なり, 堆積域の最終的な海浜縌断面 違う形状となった理由について考察する。これは，中間 地点に設置した突堤 $G_{c}$ の堤長が短く暴浪波作用時の沿 岸漂砂が通過するが, 右端の突堤 $G_{r}$ は堤長が長く暴浪 時の沿岸漂砂を完全に遮断するためと推定できる.

次に, 図一11に示したように静穏波作用後に土砂収支 が負の值に，暴浪波作用後に土砂収支が正の值になった 理由について考察する。まず, 整形後における慔型海浜 の砂粒子間の間隙が大きかったが, $t=0 \sim 190 \mathrm{~min}$ の静 


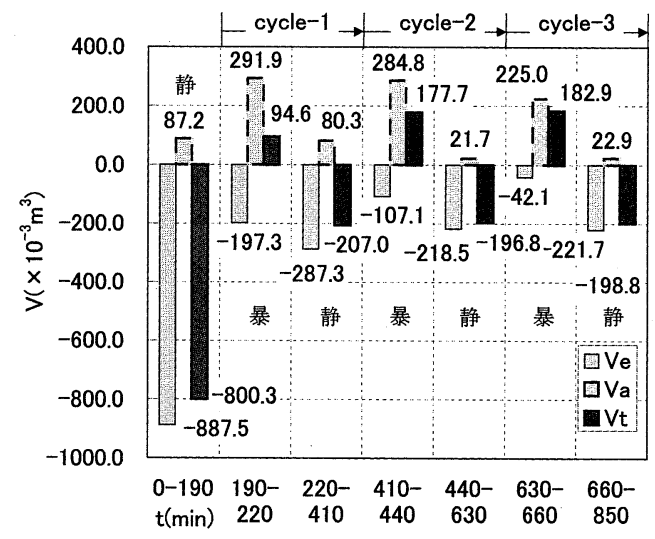

図-11 海浜縦断面の測定時間毎の土砂収支

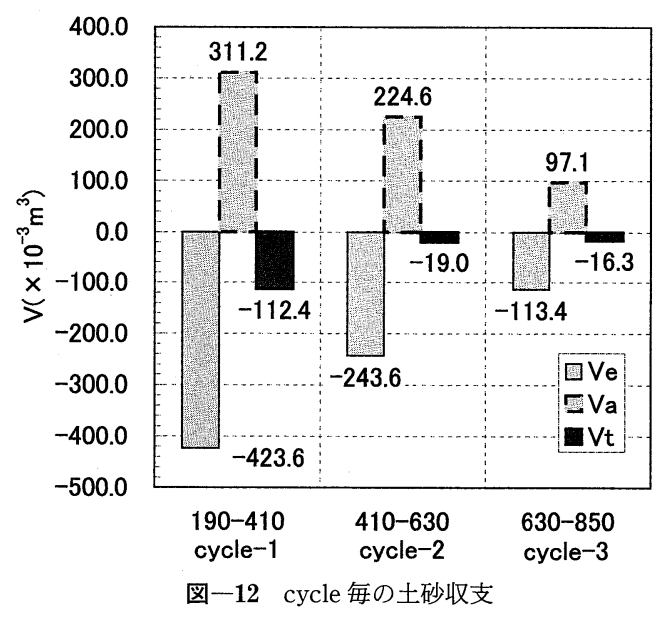

穏波の作用でほぼ全域で締め固められて砂粒子間の間隙 が小さくなり, 土砂収支が大きな負の值となった。次に, $t=190 \sim 220 \mathrm{~min}$ では暴浪波の作用で砂粒子間の間隙が 大きくなり土砂収支が増加し，t=220 410 min では静 穏波の作用で再び砂粒子間の間隌が小さくなり土砂収支 が減少した。このような砂粒子間の間隙の変化が暴浪波 と静穏波の作用で生じて, 土砂収支の不均衡が生じる. しかし，暴浪波と静穏波を継続して作用させた後では砂
粒子間の間隙はもとに戻るので, 1-cycle の土砂収支は ほほ均衡すると推定できる。

\section{5.おわりに}

本実験で対象とした沿岸漂砂が卓越する海岸の侵食域 では，暴浪波の作用による前浜の侵食と沖側でのバーの 形成，および静穏波の作用による前浜の侵食とバーの消 滅が繰り返されて, 鉛直上方に凹形の海浜縦断面となっ た. 同様に中間地点でも鉛直上方に凹形の海浜縦断面と なった。また，堆積域では暴浪波と静穏波との作用によ り砂の堆積が進み，鉛直上方に凸形の海浜縦断面となっ た.そして，土砂収支が閉じたへッドランド間では暴浪 波と静穏波を繰り返し受けると，波浪の作用に対して安 定な海浜地形になる変形過程が明らかになった。

また，本実験ではへッドランド間の土砂収支は暴浪波 作用後には増加し, 静穏波作用後には減少するが, 1-cycleではほぼ均衡することも分かった。この理由と して, 暴浪波と静穏波の作用で生じる砂粒子間の間隙の 変化を考えたが, このような現象の解明は今後の課題と して残された。そして, 現地海岸において養浜で創出し た砂浜でも，暴浪波と静穏波の作用によって砂粒子間の 間隙の変化が生じるとすれば，養浜範囲から土砂が流出 したと評価される場合があることが問題点として指摘で きる。

\section{参 考 文 献}

岡田 渉・浦南 満・出口一郎 (2000)：沿岸砂州を有する海浜 の断面変形関する研究, 海岸工学論文集, 第 47 巻, pp. 606-610.

栗山善昭（1996）：沿岸砂州の短期变動特性，海岸工学論文集， 第 43 巻, pp. 576-580.

砂村継夫・倉田雄司（1981）：時間的に変動する波浪を用いた海 浜変形に関する二次元実験, 第 28 回海岸工学講演会論文集, pp. 222-226.

福島雅紀・山本幸次・佐藤揁司（1999）：時間変動波浪を用いた 海浜変形実験, 海岸工学論文集, 第 46 巻, pp. 556-560.

山本幸次・福島雅紀・佐藤慎司 (1999)：阿字ヶ浦海岸における 長期断面変化と砂層厚, 海岸工学論文集, 第 46 巻, pp. 636-640. 